\title{
Karakterisasi Bakteri Asam Laktat Proteolitik pada Bekasam
}

\author{
Prima Retno Wikandari ${ }^{1,2 *)}$, Suparmo ${ }^{2)}$, Yustinus Marsono ${ }^{2)}$ dan Endang Sutriswati Rahayu ${ }^{2)}$ \\ ${ }^{1)}$ Fakultas Matematika Ilmu Pengetahuan Alam, Universitas Negeri Surabaya, Surabaya 60231 \\ ${ }^{2}$ Fakultas Teknologi Pertanian, Universitas Gadjah Mada, Yogyakarta 55281
}

Diterima 02-08-2010 Disetujui 21-05-2011

\begin{abstract}
Bekasam is a traditional fermented fish from Indonesia. It is made from fish in which the gills and gut had been discarded, washed, and mixed with salt, after two days, it was covered with rice and salt, and then fermented for 5-7 days at room temperature. Bekasam is perceived to have antihypertensive activity, which is though to be the activity of bioactive peptides, the product of protein degradation during the bekasam fermentation. The research was aim to isolate the indigenous lactic acid bacteria that produce strong proteolytic capabilities. The lactic acid bacteria were collected from 3 kinds of bekasam (tilapia, milkfish, and tuna bekasam). Isolation of the lactic acid bacteria was done on agar medium containing MRS $+\mathrm{CaCO}_{3}$, and the screening of the proteolytic bacteria was done by growing the isolated culture on skim agar. The colonies that produce clear zone were identified as proteolytic lactic acid bacteria. Some of 180 isolated strains of acid producing bacteria that produce clear zone on MRS agar were found 150 strains of lactic acid bacteria, and 84 strains showed their proteolytic activity. The later were identified morphologically and biochemical as Lactobacillus, Pediococcus and Leuconostoc genera. Selection was further conducted based on the height of the proteolytic and homofermentative fermentation activities. Upon species identification using API CH 50 kit, the selected strains belong to species of Lactobacillus plantarum, Lactobacillus pentosus, and Pediococcus pentosaseus.
\end{abstract}

Keywords: bekasam, fish fermentation, proteolytic lactic acid bacteria

\begin{abstract}
ABSTRAK
Bekasam adalah salah satu produk fermentasi ikan tradisional Indonesia. Bekasam terbuat dari ikan yang telah dibersihkan insang dan isi perutnya, dicuci, dicampur dengan garam. Setelah 2 hari fermentasi, pada campuran ini ditambahkan nasi dan fermentasi dilanjutkan hingga 5 sampai 7 hari. Bekasam diduga mempunyai aktivitas antihipertensi karena terbentuknya peptida bioaktif hasil degradasi protein ikan selama proses fermentasi bekasam. Penelitian ini bertujuan mengisolasi bakteri asam laktat indigenous bekasam yang mempunyai daya proteolitik tinggi. Bakteri asam laktat diisolasi dari 3 jenis bekasam (bekasam nila, bandeng dan tuna). Isolasi dilakukan dengan menggunakan medium MRS agar $+\mathrm{CaCO}_{3}$ dan screening isolat bakteri asam laktat proteolitik dilakukan menggunakan skim agar. Koloni yang memberikan zona jernih pada skim agar diidentifikasi sebagai bakteri asam laktat proteolitik. Dari 180 isolat bakteri penghasil asam yang memberikan zona jernih pada MRS agar ditemukan 150 strain bakteri asam laktat dan 84 strain diantaranya menunjukkan aktivitas proteolitiknya. Hasil pengujian lebih lanjut secara morphologi dan biokimiawi menunjukkan bahwa isolat-isolat ini merupakan genus Lactobacillus, Pediococccus dan Leuconostoc. Hasil seleksi lebih lanjut dilakukan terhadap bakteri asam laktat homofermentatif dan mempunyai aktivitas proteolitik tinggi. Hasil identifikasi spesies isolat menggunakan API CH50 menunjukkan bakteri asam laktat terpilih adalah Lactobacillus plantarum, Lactobacillus pentosus dan Pediococcus pentosaceus.
\end{abstract}

Kata kunci: bakteri asam laktat proteolitik,bekasam, fermentasi ikan

\section{PENDAHULUAN}

Produk-produk fermentasi bergaram ikan banyak dijumpai di Asia Tenggara. Bekasam adalah salah satu produk tradisional fermentasi bergaram dari ikan yang banyak dijumpai di beberapa daerah di Indonesia terutama Sumatera Selatan, Kalimantan Selatan, dan Sulawesi Utara. Pada umumnya produk ini dibuat dengan mencampurkan ikan, nasi dan garam dalam wadah tertutup dan selanjutnya dilakukan proses fermentasi pada suhu ruang antara 5 sampai 7 hari. Bekasam yang dihasilkan mempunyai karakteristik daging ikan seperti ikan segar dengan daging ikan yang

\footnotetext{
*Telp: +6281328262678

e-mail: wikandari@yahoo.com
}

semakin kenyal, rasa asam asin khas bekasam dengan aroma tertentu.

Bekasam hampir serupa dengan beberapa produk fermentasi ikan yang dijumpai di beberapa negara lainnya seperti, burong isda, burong bangus (Philipina), pla-ra, pla-chom, som-fak (Thailand), heshiko, nakazuke (Jepang). Pada dasarnya pembuatan bekasam adalah salah satu upaya pengawetan ikan yang memanfaatkan bakteri asam laktat. Penelitian tentang bakteri asam laktat pada produk fermentasi berkembang dengan ditemukannya beberapa manfaat bakteri asam laktat dalam bahan pangan antara lain penghasil bakteriosin dan manfaat lainnya dalam memberikan efek 
fisiologis tertentu yang membawa manfaat bagi kesehatan antara lain sebagai antikolesterol, mencegah kanker, dan antihipertensi.

Aktivitas antihipertensi produk fermentasi berkaitan dengan adanya aktivitas proteolitik baik oleh enzim indogenus, ataupun aktivitas enzim proteolitik bakteri asam laktat. Beberapa jenis bakteri asam laktat diketahui mempunyai aktivitas proteolitik. Bakteri asam laktat L. plantarum, L. brevis, Pediococcus dan L. ssp. yang diisolasi dari pla-ra diketahui mempunyai aktivitas proteolitik (Vichasilp et al. 2008). Pediococcus acidilactici ATCC 8042 juga menunjukkan aktivitas proteolitik ekstraseluler (Adriana et al. 2008).

Walaupun sifat antihipertensi lebih banyak diteliti pada produk susu fermentasi, tetapi beberapa penelitian menunjukkan bahwa produk fermentasi laktat pada ikan juga menunjukkan efek antihipertensi. Telah ditemukan bahwa selama proses fermentasi laktat pada ikan makarel dijumpai kenaikan peptida pada ekstrak yang diperoleh, dan diketahui dapat menurunkan tekanan darah tikus hipertensi (Itou \& Akahane 2004). Pada kecap ikan juga ditemukan peptida bioaktif (Lee et al. 2003). Peptida dengan aktivitas hipotensif juga ditemukan pada otot ikan sarden (Matsufuji et al. 1994). Ikan makarel yang difermentasi dengan L.plantarum, L.lactis, L.helveticus menghasilkan biogenik peptida antihipertensi. (Yin et al. 2002). Peptida biogenik pada ikan bonito kering yang dikenal dengan Katsuobushi juga diketahui dapat menurunkan tekanan darah (Kouno et al. 2005). Peptida Lys-Pro yang diisolasi dari kecap ikan anchovy diketahui mempunyai aktivitas antihipertensi dengan nilai $\mathrm{IC}_{50}=22$ (Kimetal. 1993).

Penelitian ini bertujuan mengisolasi dan mengidentifikasi bakteri asam proteolitik dari bekasam. Hasil penelitian lebih lanjut akan digunakan untuk mengetahui potensi bakteri asam laktat proteolitik isolat bekasam yang mampu mendegradasi protein ikan menjadi peptida antihipertensi.

\section{BAHANDANMETODE}

Pembuatan bekasam. Bekasam dibuat dari 3 macam ikan nila, tuna dan bandeng yang masing-masing dibeli dari pasar lokal di daerah Yogyakarta. Ikan dipilih yang segar, dicuci, dan dibersihkan dari insang dan isi perut, selanjutnya sebanyak masing-masing $\pm 500 \mathrm{~g}$ ikan dicampur dengan garam $10 \%$ dan diinkubasi dalam wadah plastik tertutup selama 48 jam pada suhu ruang. Proses selanjutnya adalah penambahan nasi dengan perbandingan ikan dan nasi 1:1 dan proses inkubasi dilanjutkan dalam wadah plastik tertutup sampai 7 hari pada suhu ruang. Analisis yang dilakukan adalah isolasi bakteri asam laktat, pemurnian, identifikasi bakteri asam laktat proteolitik, identifikasi genus dan spesies bakteri asam laktat proteolitik.

Isolasi Bakteri Asam Laktat. Isolasi dilakukan dari sampel 3 jenis bekasam pada hari ke 3 sampai hari ke 7 fermentasi dari 2 ulangan. Dari setiap sampel diambil 5 koloni yang memberikan zona jernih pada medium $\mathrm{MRS}$ dan $\mathrm{CaCO}_{3}$ dari metode poured plate, sehingga didapatkan 180 isolat. Selanjutnya dilakukan pemurnian dengan metode streak plate pada medium yang sama. Koloni tunggal hasil streak plate selanjutnya dilihat pada mikroskop dengan pembesaran 400x untuk dilihat morphologi kultur. Kultur murni ditandai dengan morfologi yang seragam (bulat, batang, pembentukan tetrad, tunggal, berpasangan, berantai). Terhadap isolat hasil pemurnian selanjutnya dilakukan pengujian bakteri asam laktat dilakukan dengan pengujian Gram, katalase, motilitas, ada tidaknya spora. Bakteri asam laktat adalah bakteri yang menunjukkan ciri gram + , katalase -, non motil dan tidak membentuk spora. Penyimpanan isolat dilakukan dengan cara menyimpan kultur yang berumur 24 jam pada medium MRS dan gliserol $20 \%$ (1:1) pada suhu $-60^{\circ} \mathrm{C}$.

Pengujian Bakteri Asam Laktat Proteolitik. Isolat yang memberikan ciri-ciri bakteri asam laktat selanjutnya diuji aktivitas proteolitiknya menggunakan media skim milk agar dengan komposisi $2 \%$ skim dan $2 \%$ agar. Inokulasi dilakukan dengan cara menusukkan isolat pada medium skim agar dengan tusuk gigi steril, selanjutnya diinkubasi pada suhu kamar selama 24 jam. Isolat proteolitik ditandai dengan pembentukan zona jernih pada medium skim agar dan aktivitas proteolitik diukur berdasarkan rasio diameter zona jernih/ diameter koloni (R).

Karakterisasi Genus dan Identifikasi Spesies Isolat Bakteri Asam Laktat Proteolitik. Karakterisasi genus isolat bakteri asam laktat proteolitik dilakukan pada isolat yang mempunyai aktivitas proteolitik relatif tinggi $(\mathrm{R} \geq 1,5)$ selanjutnya diuji karakteristik biokimiawinya dengan pengujian pertumbuhan pada berbagai suhu, $\mathrm{pH}$ dan kadar garam serta uji pembentukan gas hasil fermentasi glukosa. Pengujian dilakukan dengan melihat pertumbuhan isolat pada medium MRS broth pada berbagai kondisi yang ditentukan. Penentuan genus didasarkan pada Bergey's Manual of Systematic Bacteriology berdasarkan 
karaskteristik fenotipik yang dihasilkan masing-masing isolat. Identifikasi spesies dilakukan pada isolat proteolitik terpilih ( $\mathrm{R} \geq 2$, homofermentatif) dengan pengujian pola fermentasi karbohidrat dari masing-masing isolat dengan sistem API $50 \mathrm{CH}$. Penentuan jenis spesies dilakukan dengan software apiweb ${ }^{\mathrm{TM}}$ data base V5.1.

\section{HASIL DAN PEMBAHASAN}

Screening bakteri asam laktat proteolitik. Screening bakteri asam laktat proteolitik diawali dengan isolasi bakteri asam laktat. Dari total 180 koloni bakteri yang memberikan zona jernih pada medium MRS dan $\mathrm{CaCO}_{3}$, didapatkan sebanyak 150 isolat yang menunjukkan ciri bakteri asam laktat yaitu masing-masing 42 isolat dari bekasam nila, 53 isolat dari bekasam bandeng, dan 55 isolat dari bekasam tuna. Contoh isolat penghasil zona jernih pada medium MRS dan $\mathrm{CaCO}_{3}$ seperti Gambar 1. Terhadap seluruh isolat bakteri asam laktat selanjutnya dilakukan pengujian bakteri asam laktat yang mempunyai aktivitas proteolitik yang ditunjukkan

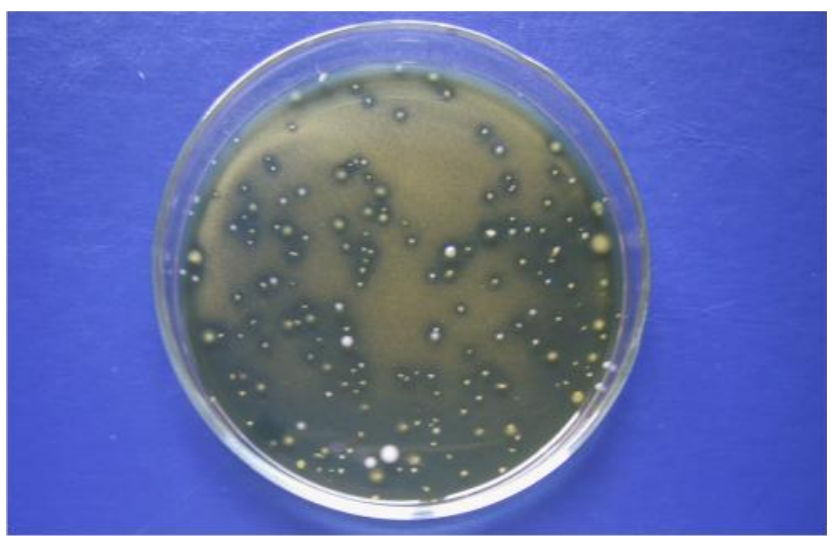

Prima doc 200

Gambar 1 Koloni bakteri pembentuk zona jernih medium MRS + $\mathrm{CaCO}_{3}$ pada pengenceran dan plating $10^{-7}$

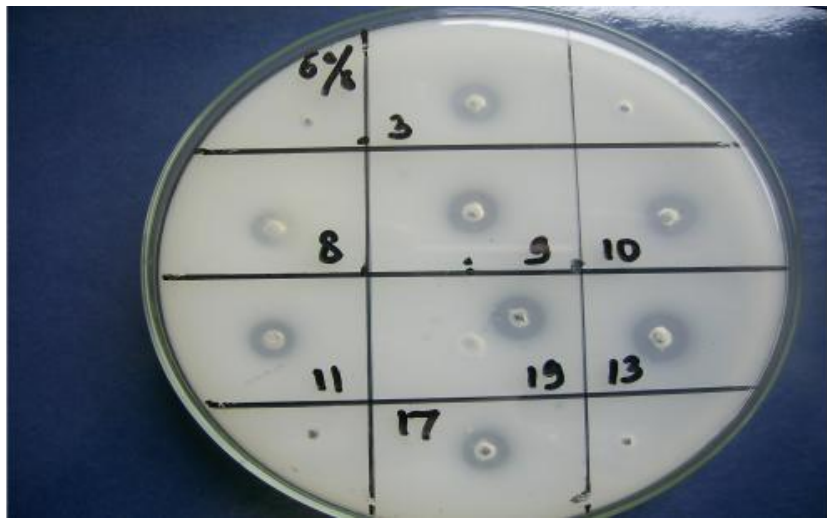

Prima doc 2009

Gambar 2 Pembentukan zona jernih pada media skim agar oleh bakteri asam laktat proteolitik dari bekasam dengan kemampuannya memberikan zona jernih pada medium skim agar (Gambar 2).

Pada bekasam nila ditemukan bakteri asam laktat yang mempunyai aktivitas proteolitik sebanyak 64,2\% (27 dari 42 isolat bakteri asam laktat), pada bekasam bandeng dan bekasam tuna masing-masing ditemukan sebanyak 62,26\% (33 dari 53 isolat bakteri asam laktat), dan 43,63\% (24 dari 55 isolat bakteri asam laktat). Jika dilihat dari aktivitas proteolitik ditinjau dari ukuran rasio zona jernih/diameter koloni (R), maka jumlah isolat yang menunjukkan aktivitas proteolitik tinggi $(\mathrm{R} \geq 1,5)$ lebih sedikit dibandingkan isolat bakteri dengan $\mathrm{R} \leq 1,5$ (Tabel 1).

Berdasarkan besarnya nilai $\mathrm{R}$ menandakan bahwa kemampuan proteolitik isolat bakteri asam laktat sangat beragam diantara level genus maupun strain pada spesies yang sama. Pada plara diketahui bahwa aktivitas proteolitik sangat beragam, ditemukan $\mathrm{R}$ sebesar 1,66 untuk genus Pediococcus, akan tetapi juga ditemukan $\mathrm{R}$ yang sama 1,66 pada genus Lactobacillus, sedangkan strain Lactobacillus yang lain mempunyai $\mathrm{R}=2,71$ (Vichasilp et al. 2008).

Karakterisasi genus bakteri asam laktat proteolitik. Pengujian lebih lanjut dilakukan untuk mengetahui genus isolat bakteri asam laktat proteolitik dengan melihat karakteristik morfologi dan biokimiawi isolat, meliputi kemampuan menghasilkan gas dari glukosa dan pertumbuhan masing-masing isolat berbagai suhu, kadar garam, dan $\mathrm{pH}$. Pengujian karakteristik kimiawi hanya dilakukan pada isolat dengan aktivitas proteolitik relatif tinggi $(\mathrm{R} \geq 1,5)$.

Berdasarkan Bergey's Manual of Systematic Bacteriology dari hasil identifikasi morfologi dan pengujian biokimiawi seperti pada Tabel 2 dapat diketahui bahwa bakteri asam laktat proteolitik terpilih dari bekasam dapat dikategorikan dalam 3 (tiga) kelompok yaitu genus Lactobacillus, dan Pediococcus dan Leuconostoc.

a. Genus Lactobacillus. Jenis bakteri asam laktat Lactobacillus dicirikan dengan isolat berbentuk batang, gram positif dan katalase negatif. Isolat terpilih memberikan

Tabel 1 Jumlah isolat bakteri asam laktat dan bakteri asam proteolitik pada bekasam

\begin{tabular}{lccc}
\hline \multicolumn{1}{c}{ Jenis isolat } & \multicolumn{3}{c}{ Jumlah isolat } \\
\cline { 2 - 4 } & Nila & Bandeng & Tuna \\
\hline Bakteri pembentuk asam & 60 & 60 & 60 \\
Bakteri Asam Laktat (BAL) & 42 & 53 & 55 \\
BAL proteolitik & 27 & 33 & 24 \\
BAL proteolitik R $\geq 1,5$ & 6 & 9 & 7 \\
BAL proteolitik R $\leq 1,5$ & 21 & 24 & 17 \\
BAL non proteolitik & 15 & 20 & 31 \\
\hline
\end{tabular}


karakteristik ada yang menghasilkan gas dan tidak menghasilkan gas hasil fermentasi glukosa. Oleh sebab itu isolat Lactobacillus terpilih yang ditemukan dalam bekasam tergolong dalam Lactobacilus homofermentatif dan heterofermentatif. Karakteristik lainnya adalah semua isolat Lactobacillus dari isolat terpilih menunjukkan ciri masih dapat tumbuh hingga kadar garam 6,5\%, dan $\mathrm{pH} 4,2$.

Semua isolat Lactobacillus terpilih dapat tumbuh pada suhu $15^{\circ} \mathrm{C}$. Jika dilihat dari karakteristik tersebut, maka jenis isolat ini tergolong dalam Lactobacillus mesofilik, walaupun mayoritas isolat juga tetap menunjukkan pertumbuhan pada $45^{\circ} \mathrm{C}$, hanya 1 isolat Lactobacillus yang tidak dapat tumbuh pada $45^{\circ} \mathrm{C}$. Menurut Bergey's Manual of Systematic Bacteriology, ciri bakteri asam laktat mesofilik adalah yang dapat tumbuh pada suhu $15^{\circ} \mathrm{C}$, akan tetapi tidak dapat tumbuh pada $45^{\circ} \mathrm{C}$. Kemungkinan hal ini disebabkan karena perbedaan habitat tumbuhnya, yaitu bakteri yang tumbuh pada iklim tropis. Ciri lain yang menyimpang adalah semua isolat bakteri asam laktat dari bekasam menunjukkan kemampuan untuk tetap dapat tumbuh pada $\mathrm{pH}$ 9,6.

b. Genus Pediococcus dan Leuconostoc. Ditemukan isolat berbentuk bulat, membentuk tetrad dan tidak menghasikan gas yang diduga adalah genus Pediococcus. Menurut Bergey's Manual Identification, Pediococcus dapat dibedakan dari isolat berbentuk bulat lainnya dari ciri membentuk tetrad dan tidak menghasilkan gas. Pediococcus

Tabel 2 Karakteristik fenotip bakteri asam laktat proteolitik bekasam $(\mathrm{R} \geq 1,5)$

\begin{tabular}{|c|c|c|}
\hline Karakteristik & Kelompok I & Kelompok II \\
\hline Bentuk sel & Batang & Bulat \\
\hline Bentuk tetrad & - & + \\
\hline Produksi gas & $+/-$ & $-/+$ \\
\hline Pembentukan spora & - & - \\
\hline Pewarnaan gram & + & + \\
\hline Catalase & - & - \\
\hline Motilitas & - & - \\
\hline Tipe fermentasi & Homo/hetero & Homo/hetero \\
\hline Kadar garam $6,5 \%$ & + & + \\
\hline Kadar garam $10 \%$ & - & - \\
\hline Kadar garam $18 \%$ & - & - \\
\hline Pertumbuhan $10^{\circ} \mathrm{C}$ & - & - \\
\hline Pertumbuhan $15^{\circ} \mathrm{C}$ & + & $+/-$ \\
\hline Pertumbuhan $45^{\circ} \mathrm{C}$ & $+/-$ & + \\
\hline Pertumbuhan $50^{\circ} \mathrm{C}$ & - & - \\
\hline Pertumbuhan $\mathrm{pH} 4,2$ & + & + \\
\hline Pertumbuhan $\mathrm{pH} 8,4$ & + & + \\
\hline Pertumbuhan $\mathrm{pH} 9,6$ & + & + \\
\hline Genus & Lactobacillus & Pediococcus, Leuconostoc \\
\hline Strain & $\begin{array}{c}\text { Lactobacillus } \\
\text { N2352,N1441, } \\
\text { N21065, } \\
\text { B1465,B1555, } \\
\text { B2555,B1765, } \\
\text { T2565, T1761 }\end{array}$ & $\begin{array}{c}\text { Pediococcus N1351, } \\
\text { N2761, N21061, } \\
\text { B1453,B1661; } \\
\text { T2562,T2672, } \\
\text { T2671,T21064,T21062 } \\
\text { Leuconostoc B1341, } \\
\text { B11061, B11065 }\end{array}$ \\
\hline
\end{tabular}

Keterangan : Kode isolat: B (bandeng); N (nila); T (tuna) dicirikan juga dengan kemampuan isolat untuk tumbuh pada pH 8,6 dan $\mathrm{pH} 4,2$, serta tumbuh pada suhu $45^{\circ} \mathrm{C}$. Semua isolat berbentuk bulat, tetrad yang diisolasi dari bekasam menunjukkan ciri tersebut. Karakteristik lainnya mayoritas isolat Pediococcus menunjukkan ciri tidak tumbuh pada suhu $15^{\circ} \mathrm{C}$, hanya 2 isolat yang mampu tumbuh pada $15^{\circ} \mathrm{C}$, dan semua isolat mampu tumbuh pada suhu $45^{\circ} \mathrm{C}$, tetapi tidak dapat tumbuh pada $50^{\circ} \mathrm{C}$.

Ditemukan juga isolat berbentuk bulat, tidak membentuk tetrad dan menghasilkan gas, diduga isolatisolat ini merupakan genus Leuconostoc. Leuconostoc akan memfermentasi gula menjadi asam laktat, asam asetat, etanol dan $\mathrm{CO}_{2}$. Terbentuknya gas $\mathrm{CO}_{2}$ membedakan Leuconostoc dari bakteri asam laktat berbentuk bulat lainnya yang bersifat homofermentatif seperti Streptococcus, Lactococcus, dan Pediococcus.

Identifikasi spesies bakteri asam laktat proteolitik. Identifikasi strain bakteri asam laktat proteolitik hanya dibatasi pada bakteri asam laktat proteolitik yang mempunyai $\mathrm{R} \geq 2,00$ dan tidak menghasilkan gas. Pemilihan isolat ini didasarkan pada penerapan isolat untuk menghasilkan peptida antihipertensi, yang pada penelitian ini baru dibatasi pada bakteri asam laktat proteolitik tinggi dan homofermentatif. Terpilih 6 isolat yaitu 5 isolat N2352; B2555; B1765; T2565, B1465 dari genus Lactobacillus dan 1 isolat B1661 dari genus Pediococcus. Genus Leuconostoc tidak masuk dalam kategori isolat terpilih karena sifatnya yang heterofermentatif, walaupun ada yang menunjukkan nilai $\mathrm{R} \geq 2,00$.

Isolat terpilih selanjutnya diidentifikasi spesiesnya dengan diuji kemampuannya dalam memfermentasi berbagai jenis karbohidrat dan derivatifnya menggunakan perangkat API CH 50 (Tabel 3). Pengujian dengan API CH 50 dilanjutkan analisis dengan software apiweb ${ }^{\mathrm{TM}}$ data base V5,1 menunjukkan bahwa Lactobacillus terpilih memberikan kemiripan dengan L. plantarum sebanyak 4 isolat yaitu L. plantarum N2352, Lactobacillus plantarum B1765, L. plantarum T2565, Lactobacillus plantarum B1465 dan 1 isolat menunjukkan kemiripan L. pentosus, yaitu L. pentosus B2555. Spesies L. plantarum dan L. pentosus ini mempunyai kemiripan karakteristik, kecuali perbedaan dalam menghasilkan asam dari D-xylosa, D-melizitosa, metil-áDmannopiranisida, metil- $\alpha \mathrm{D}$-glukopiranosida, dan gliserol. Hasil pengujian isolat Pediococcus dengan API CH 50 menunjukkan spesies yang mempunyai kemiripan dengan 
Tabel 3 Perbedaan hasil uji gula dengan API CH 50 dari bakteri asam laktat proteolitik bekasam

\begin{tabular}{|c|c|c|c|c|c|c|c|}
\hline No & Tipe gula & $\begin{array}{c}\text { Pediococcus } \\
\text { B1661 }\end{array}$ & $\begin{array}{c}\text { Lactobacillus } \\
\text { B2555 }\end{array}$ & $\begin{array}{c}\text { Lactobacillus } \\
\text { B1765 }\end{array}$ & $\begin{array}{c}\text { Lactobacillus } \\
\text { B1465 }\end{array}$ & $\begin{array}{c}\text { Lactobacillus } \\
\text { N2352 }\end{array}$ & $\begin{array}{c}\text { Lactobacillus } \\
\text { T2565 }\end{array}$ \\
\hline 1 & D-xylosa & + & + & - & - & - & - \\
\hline 2 & D-manitol & & + & + & + & + & + \\
\hline 3 & D-sorbitol & - & + & + & + & + & + \\
\hline 4 & Metil- $\alpha \mathrm{D}$-manopiranosida & - & - & + & + & + & + \\
\hline 5 & Metil- $\alpha$ D-glukopiranosida & - & + & - & - & - & - \\
\hline 6 & D-laktosa & - & + & + & + & + & + \\
\hline 7 & D-melibiosa & - & + & + & + & + & + \\
\hline 8 & D-sacharosa & - & + & + & + & + & + \\
\hline 9 & D-melizitosa & - & + & + & + & + & + \\
\hline 10 & D-turanosa & - & + & + & + & + & + \\
\hline 11 & D-tagatosa & + & - & - & - & - & - \\
\hline 12 & K-glukonat & - & + & + & + & + & + \\
\hline 13 & Gliserol & - & + & - & - & - & - \\
\hline
\end{tabular}

Reaksi (+) semua isolat : L-arabinosa, D-ribosa, D-galaktosa, D-glukosa,D-fruktosa, D-manosa, N-acetilglukosamin, amigdalin, arbutin, esculin, salcine, D-cellobiosa, D-maltosa, D-trehalosa, gentiobiosa.

Reaksi (-) semua isolate: erittriol, D-arabinosa, L-xilosa, D-adenitol, metil- $\beta$ D-xilopiranosida, L-sorbosa, L-rhamnosa, dulsitol, inositol, inulin, amidol, glikogen, xylitol, D-lixosa, D-fucosa, L-fucosa, D-arabitol, L-arabitol, K-2-Ketoglokonat, K-5-ketoglukonat.

Tabel 4 Hasil Interpretasi Isolat Bakteri Asam Laktat Proteolitik Bekasam dengan software apiweb ${ }^{\mathrm{TM}}$ data base V5,1.

\begin{tabular}{lccc}
\hline No & Kode Isolat & Dugaan Jenis Isolat & \% Kemiripan \\
\hline 1 & N2352 & L.plantarum 1 & 99,7 \\
2 & T2565 & L.plantarum 1 & 99,9 \\
3 & B1765 & L.plantarum 1 & 99,9 \\
4 & B1465 & L.plantatum 1 & 86,1 \\
5 & B2555 & L.pentosus & 84,3 \\
6 & B1666 & Pediococcus pentosaseus & 99,9 \\
\hline
\end{tabular}

Pediococcus pentosaseus yaitu isolat Pediococcus pentosaseus B1661. Hasil interpretasi isolat bakteri asam laktat proteolitik bekasam dengan software apiweb ${ }^{\mathrm{TM}}$ data base V5,1 seperti pada Tabel 4.

Hasil penelitian ini didukung oleh beberapa penelitian sebelumnya. Terkait dengan bahan dasar ikan maka didapatkannya L. plantarum sesuai dengan penelitian bahwa spesies ini adalah spesies yang mayoritas tumbuh ikan dan udang (Nair \& Puthuvalil 2005). L. plantarum ditemukan dalam usus beberapa jenis ikan air tawar (Scorta 2007). Pediococcus pentosaseus ditemukan diantara isolat yang diisolasi dari saluran pencernaan ikan laut (Buntin et al. 2008). Terkait dengan produk-produk ikan fermentasi maka hasil ini juga didukung oleh penemuan-penemuan sebelumnya. Pada produk fermentasi ikan "plasom" ditemukan bakteri asam laktat L. plantarum, L.acidophilus, L. fermentum, L. pentosus, L. reuteri (Panthavee et al. 2007). Pada beberapa produk ikan fermentasi Thailand dijumpai bakteri asam laktat jenis L. pentosus, L. plantarum, L. farciminis, L. spp, dan Leuconostoc (Tanapasuwat \& Komagata 1988). Christine et al. (2002), menemukan Leuconostoc, L. curvatus, L. lactis adalah bakteri asam laktat yang tumbuh pada awal proses fermentasi "somfak", diikuti oleh pertumbuhan L. casei, L. pentosus dan L. plantarum. Pada beberapa produk ikan fermentasi dari India ditemukan jenis Lactococcus lactis, E. faecium, L. coryniformis, L. plantarum (Thapa et al. 2004).

Diketemukannya spesies L. plantarum sebagai salah satu isolat yang mempunyai aktivitas proteolitik juga ditunjukkan oleh beberapa penelitian (Cagno et al. 2002; Basso et al. 2004; Fadda et al. 1998). Aktivitas proteolitik Pediococcus pentosaceus ditemukan pada pla- som (Vichasilp et al. 2008), dan pada sosis (Dalmis \& Soyer 2008). Hasil penelitian tentang sifat-sifat biokimia bakteri asam laktat dari makanan fermentasi di Asia Tenggara menunjukkan bahwa E. faecalis, E. lactis, Leuconostoc mesentroides, L. acidophilus, L.casei, L. plantarum, adalah bakteri asam laktat yang mempunyai aktivitas proteolitik (Ohhira \& lichiroh 1999).

\section{SIMPULAN}

Dari 180 isolat bakteri pembentuk asam, ditemukan 150 strain bakteri asam laktat, dan 84 strain diantaranya menunjukkan aktivitas proteolitik. Hasil screening dan identifikasi lebih lanjut tentang jenis spesies pada bakteri asam laktat proteolitik terpilih ( $\mathrm{R} \geq 2,0$, homofermentatif) dihasilkan 6 isolat dari strain L. plantarum 1 yaitu L. plantarum N2352, L. plantarum B1765, L. plantarum T2565, L. plantarum B1465 dan 1 isolat menunjukkan kemiripan L. pentosus, yaitu L. pentosus B2555, dan Pediococcus pentosaseus B1666.

\section{DAFTAR PUSTAKA}

Adriana, L.B., Perez., Mungula, S \& Farres, A. 2008. Novel extracelluler proteolytic in pediococcus acidilactici ATCC 8042. Can J Microbiol 54(8): 694-699.

Basso, A.L., Picariello, G., Coppola, R., Tremonte, P., Musso, S.S \& Luccia, A.D. 2004. Proteolytic activity of Lactobacillus sakei, Lactobacillus farciminis and Lactobacillus plantarum 
on Sarcoplasmic protein of pork lean. J Food Biochem28: 195-212

Buntin, N., Suphitchaya, C., Tipparat, H \& Songklanakarih. 2008. Screening of lactic acid bacteria from gastrointestinal tracks of marine fish for their potensial use as probiotics. $J$ Sci Technol 30(1): 141-148.

Cagno, R.D., Angelis, M.D., Lavermicocca, P.,Vicenzi, M.D., Giovannini, C., Faccia, M \& Gobetti, M. 2002. Proteolysis by sourdough lactic acid bacteria: Effect on wheat flour protein fraction and gliadin peptide involved in human cereal intolerance. Appl Environ Microb 68(2): 623-633.

Christine, P.M., Mette, M., Pairat, C., Lone, G \& Peter, L.M. 2002. Fermentation and microflora of plaa-som, a thai fermented fish product prepared with different salt consentration. Int J Food Microbiol 73(1): 61-70.

Dalmis, U \& Soyer, A. 2008. Effect of processing methods and starter culture (Staphylococcus xylosus and pediococcus pentosaceus) on proteolytic changes in turkish sausage (sucuk) during ripening and strorage. Meat science 80(2): 345-354.

Fadda, S., Graciella, V., Aida, P.R.H \& Guilermo, O. 1998. Proteolytic activity of Lactobacillus strain from dry fermented sausage on muscle sarcoplacmic protein. Meat Science 49(1): $11-18$.

Itou, K \& Akahane, Y. 2004. Antihypertensive effect of heshiko, a fermented mackarel product, on spontaneously hypertensive rat. Fish Sci 70(6): 1121-1129.

Kim, S.B., Lee, T.G., Park, Y.B., Yeum, D.M., Kim, O.K., Gyun, H.S \& Park, Y.H. 1993. Characteristic of angiotensin inhibitory converting enzyme derived from fermented fish product (Salted and Fermented Anchovy). Bull Korean Fish Soc 26(4): 321-329.

Kouno, K., Shin-ichi H., Hiroshi, K., Midori K \& Keiko, H. 2005. Effect on dried bonito (Katshuobushi) and captopril, an angiotensin-i-converting enzyme inhibitor, on rat isolated aorta: a possible mechanism of antihypertensive action. Biosci Biotechnol Biochem 69(5): 911-915.

Lee, H.C. 2003. Creative Fermentation Technology for The Future. http://seafooduedavis.edu/iufost/lee.htm
Matsufuji, H., Matsui, T \& Seki E. 1994. Angiotensin-i-converting enzyme inhibitory peptide in an alkaline protease hydrolysate derived from sardine muscle. Biosci Biotechnol Biochem 58(12): 2244-2245.

Minerva, O., Ono H., Shinmyo. A \& Takano, M. 1991. Lactic acid bacteria in fermented fishery product "Burong-Bangus". J Ferment Bioeng 73(3): 193-197.

Nair, P.S \& Puthuuvalil, K.S. 2005. Biochemical characterization of lactic acid bacteria isolated from fish and prawn. J Cult Collect (4)p: 48-52.

Ohhira \& Iichiroh. 1999. Distribution and biochemical properties of lactic acid bacteria from traditional fermented food in south east asia. Research Paper. Symposium on Oral Recurrent Aphthous Ulceration, Epidemiology, Clinicopathology and Management. Faculty of Dentistry, University of Malaya, Kuala Lumpur, Malaysia.

Panthavee, W., Pramuan, S \& Nasakom, W. 2007. Identification and evaluation of lactic acid bacteria for plaa-som (Fermented Fish) starter. Abstract The $2^{\text {nd }}$ International Conference on Fermentation Technology for Value Added Agricultural Products, Thailand.

Scorta \& Nicodemus. 2007. Characterization of lactic acid bacteria from freshwater intestine. Thesis. Jakarta: Universitas Katolik Atmajaya.

Tanapasuwat, S \& Komagata, K. 1995. Lactic acid bacteria in fermented foods in thailand. World J Microb Biot 11(3): 253-256.

Thapa, N., Joydep, P \& Iyoti, P.T. 2004. Microbial diversity in ngari, hentak and tungtap, fermented fish product of northeast india. World J Microb Biot 20(6): 599-607.

Vichasilp, C., Sangjindavon. M \& Wiliapun, P. 2008. The use of selected lactic acid bacteria isolates for accelaration of fermented fish (Pla-ra) process. Kasetsart university fisheries research bulletin $32(3)$ p: $17-25$.

Yin, L.J, Pan, C-I \& Jiang, S.T. 2002. Effect of lactic acid bacterial fermentation on the characteristics of minced mackerel. J Food Sci 67(2): 786-792. 